\title{
Nijemci u Slavoniji: od suživota preko stigme do reafirmacije nacionalnog identiteta
}

\author{
Dragutin Babić \\ Institut za migracije i narodnosti, Zagreb, Hrvatska \\ e-mail:dragutin.babic@imin.hr
}

SAŽETAK U ovom se radu analizira njemačka nacionalna manjina u Osijeku i Baranji na temelju empirijskog istraživanja (intervjui) provedenog u Osijeku i Belom Manastiru. Pitanja u intervjuima obuhvatila su sjećanja Nijemaca (Podunavskih Švaba) u odnosu na dolazak i prijem njihovih predaka, preko suživota koji su uspostavili s Hrvatima, Srbima, Mađarima i drugima pa do događaja iz Drugog svjetskog rata, koji su radikalno promijenili brojčano stanje, sociostatusnu poziciju i cjelokupnu egzistenciju pripadnika te nacionalne zajednice. Dio Folksdojčera s oduševljenjem je dočekao nacionalsocijalističku mobilizaciju u Kulturbundu, a u samom se ratu dio Nijemaca aktivirao u njemačkim vojnim postrojbama, što je teško narušilo predratne međunacionalne odnose u lokalnim zajednicama. Kroz ratne aktivnosti partizana i pogotovo pobjedu u ratu i formiranje nove vlasti, stigma okupatora i neprijatelja obuhvatila je njemačku nacionalnu zajednicu gotovo u potpunosti. Mali izuzetak činili su Nijemci sudionici narodnooslobodilačkog rata i oni koji su tretirani kao simpatizeri i pomagači. Za ostale, a to je bila velika većina, uslijedilo je protjerivanje iz vlastitih domova, logori, ubojstva i izbjeglištvo. Socijalistička paradigma interpretacije Drugog svjetskog rata bila je uglavnom binarna, $s$ izrazitom dihotomijom Mi/dobro - Oni/zlo, što je sakrilo mnoge niše unutar tih događanja, posebno one na mikrorazini, koje nisu bile jednostavne i jednoznačne. Poraženi, a u tu su skupinu generalizacijom obuhvaćeni Nijemci gotovo u cjelini, nisu imali pravo na sjećanje. Stigma je bila izrazito snažna i nije bilo uputno, a u prvim poslijeratnim godinama bilo je i opasno, svako sjećanje na Drugi svjetski rat koje nije bilo u okviru službene ideologije. Tek 1990. godine raspad socijalizma i federativne države te uvođenje elementarnih demokratskih uzusa u javni prostor omogućili su destigmatizaciju njemačke nacionalne manjine. Intervjuirani su Nijemci u komunikacijskom sjećanju sačuvali znanje o dolasku svojih predaka, problemima s kojima su se suočavali, prvim oblicima suživota, kao i njegovoj teškoj destrukciji u Drugom svjetskom ratu i poraću. Obnova nacionalnog identiteta nakon devedesetih godina prošlog stoljeća osnažila je malobrojnu njemačku zajednicu i omogućila njezinu vidljivost u javnom prostoru, usporavanje pa i zaustavljanje asimilacije, destigmatizaciju i izlazak iz etnomimikrije.

Ključne riječi: Nijemci, Slavonija, suživot, stigma, nacionalni identitet. 


\section{Uvod}

Hrvatska je multinacionalna država u kojoj su, pored većinskih Hrvata, službeno registrirane ukupno dvadeset dvije nacionalne/etničke manjine, uz one njezine državljane koji se nacionalno ne izjašnjavaju. U bližoj i daljoj prošlosti broj, udio, normativni status i egzistencijalni/sigurnosni aspekti pojedinih nacionalnih/etničkih manjina mijenjali su se u zavisnosti od različitih činilaca, od kojih su među važnijima: ekonomske krize, ratovi, promjene društvenih poredaka i državnih okvira. Posljednja su takva događanja kolaps socijalizma kao poretka, tranzicija u tržišno gospodarstvo i demokratski politički sustav te ratni raspad SFRJ i političko konstituiranje Republike Hrvatske. Kod značajnog broja etničkih/nacionalnih manjina dogodile su se promjene u odnosu na prethodno razdoblje, a Nijemci su svakako jedna od tih nacionalnomanjinskih zajednica s izrazitim posebnostima pri tom, što će biti predmetom analize u ovom radu. Do prije Drugog svjetskog rata vrlo brojna nacionalna zajednica u Jugoslaviji i u Hrvatskoj u samom ratu i neposrednom poraću svedena je na gotovo simbolički broj, uz to stigmatizirana i opterećena ratnim ulogama značajnog broja Folksdojčera ${ }^{1}$ i njihovim aktivnostima u provedbi ili barem podršci Hitlerovoj nacionalsocijalističkoj politici. Bilo je i onih Nijemaca koji su bili pasivni u tom vremenu, a manji broj pripadnika pristupio je partizanskom pokretu. Nijemci su formirali partizansku jedinicu Ernst Tählmann, osnovanu sredinom kolovoza 1943. g. kod Slatinskog Drenovca, od boraca iz redova njemačke nacije u sklopu 18. Slavonske udarne brigade. Nakon završetka Drugog svjetskog rata i pobjede antifašističkog pokreta uslijedili su odlasci i protjerivanja Folksdojčera u Njemačku, ubojstva i logori, a stigmatizacija pripadnika te nacionalne zajednice, $s$ različitim intenzitetom, trajala je tokom cjelokupnog razdoblja socijalističke Jugoslavije. Promjenom sustava i raspadom bivše države u odnosu prema njemačkoj nacionalnoj zajednici i u njoj samoj događaju se promjene, koje su obuhvaćene pitanjima u intervjuu koja su korištena kao predložak empirijskog istraživanja provedenog u Osijeku i Belom Manastiru. U višestoljetnom obitavanju i življenju Nijemaca u Slavoniji na razini lokalnih zajednica uspostavljena je međunacionalna koegzistencija (suživot) s brojnim nacionalnim zajednicama, prije svih s Hrvatima, Srbima i Mađarima, koji su najbrojniji u tom socioprostornom ambijentu. Ratovi, revolucije i slične društvene turbulencije, koje prate strukturalne promjene i s njima korespondiraju, uzrokovali su problem pa i destrukciju dugotrajno građenih mreža primarnih socijalnih odnosa (susjedstvo, prijateljstvo, generacijske i bračne veze) u multinacionalnim lokalnim zajednicama. Posebno teško razaranje tih mreža, gotovo u potpunosti u slučaju Nijemaca, dogodilo se u Drugom svjetskom ratu. Ovdašnji su

\footnotetext{
${ }^{1}$ U radu se koriste termini Nijemci, Folksdojčeri i Podunavske Švabe. I dok je prvi vezan za njemačku naciju u službenoj terminologiji, druga se dva odnose na kolokvijalno i uobičajeno poimanje Nijemaca u Slavoniji, povezano s konkretnim povijesnim zbivanjima. Tako se termin Folksdojčer počeo koristiti tridesetih godina 20. stoljeća za Nijemce izvan Njemačke, u Istočnoj i Srednjoj Europi, za razliku od Reichsdojčera, koji su živjeli u Njemačkoj. Isti termin obuhvaća jednim dijelom i Podunavske Švabe koji su živjeli na širem panonskom prostoru.
} 
Folksdojčeri u određenom broju sudjelovali ili barem podržali njemački nacionalsocijalizam, što ih je stavilo u funkciju okupatorske sile i konfrontiralo sa segmentima populacije koja je sudjelovala u aktivnom otporu Trećem Reichu i njegovim domicilnim pomagačima. Posljedice su bile dugotrajne, praćene stigmatizacijom pripadnika njemačke nacionalne zajednice i stradanjem velikog broja Nijemaca. Cilj empirijskog istraživanja bila je spoznaja o tome kako Nijemci u vremenu istraživanja percipiraju vlastiti status, nadalje sve ono što su pripadnici njemačke nacionalne zajednice činili u Drugom svjetskom ratu i što se događalo njihovim sunarodnjacima u poraću kao i u vremenskoj perspektivi koja uključuje nekoliko desetljeća, od uspona nacionalsocijalizma tridesetih godina dvadesetog stoljeća do kolapsa socijalizma devedesetih. Pritom će se analizirati sjećanje/pamćenje Nijemaca u Slavoniji, koje će obuhvatiti dolazak, prijem i suživot, aktiviranje na nacionalsocijalističkoj platformi, stigmatizaciju i stradanje u Drugom svjetskom ratu te obnovu nacionalnog identiteta u vremenu konstituiranja samostalne hrvatske države.

\section{Nijemci u Slavoniji od prvih doseljavanja do 21. stoljeća}

Nijemci su u Slavoniji, Hrvatskoj i u Jugoslaviji sve do Drugog svjetskog rata činili brojnu nacionalnu zajednicu. ${ }^{2}$ U Popisima stanovništva za vrijeme postojanja Kraljevine SHS, kasnije Jugoslavije (Popis 1921., 1931.), u Jugoslaviji je živjelo nešto više od 500000 Nijemaca (Geiger, 2008.), a u Hrvatskoj, prema procjenama (iako ne obuhvaćaju neke dijelove Dalmacije i Istre), između 130000 i 200000 Nijemaca (BeusRichembergh, 2010.). To su bili najveći brojčani dosezi Nijemaca na tim državnim i zemljopisnim prostorima, a drastičan će pad uslijediti u Drugom svjetskom ratu i u neposrednom poraću. Nijemci se u Hrvatskoj spominju još u 13. stoljeću, i to u Varaždinu, Samoboru, Petrinji, Zagrebu, Vukovaru i drugim naseljima. U to vrijeme njemački su se doseljenici bavili trgovinom ${ }^{3}$, obrtom i rudarstvom (Geiger, 2005.). Sa stajališta broja i društvenog utjecaja te nacionalne zajednice važniji su valovi koloniza-

\footnotetext{
2 Nijemci, njihove sudbine od doseljavanja, suživota s domicilnim stanovništvom, uloga u Drugom svjetskom ratu i teških stradanja u poraću, tema su brojnih književnih djela. Izdvajamo neka od njih. Tako Ivana Šojat-Kuči u romanu Unterstadt piše: "U svibnju 1945. naoružani partizani u kamionima u ranu zoru počeli su upadati u kuće 'Švaba' i izdajnika. Jakov je čuo galamu i istrčao na ulicu. Vidio je kako nas trpaju u kamion, u prikolicu s ceradom, kao stoku. Pokušao ih je spriječiti da nas odvedu, mene i moje roditelje. Vikao je da smo pošteni ljudi koji nikada nikome nisu učinili ništa nažao, da jamči za nas. Nije vrijedilo. Stari Jakov mi je rekao da se jedan mladi partizan samo podmuklo nasmijao i rekao da nas vraćaju Hitleru" ((Šojat-Kuči, 2009.:124). Navodimo još neke primjere iz književnosti relevantne za navedenu problematiku. Šnajder, Slobodan (2016.), Doba mjedi. Zagreb. TIMpress. 2. izdanje, Bauer, Ludwig (1990.), Kratka kronika porodice Weber. Sarajevo: Svjetlost. Jergović, Miljenko (2013.), Rod. Zaprešić. Fraktura.

3 Nijemci kao trgovci koristili su vodene puteve Dunav i Dravu, zatim željezničku prugu Zagreb - Budimpešta, izgrađenu 1870. godine. Njemačkim trgovcima konkurirali su grčki trgovci, Cincari i srpski trgovci (Kolar-Dimitrijević, 2001.).
} 
cije koji se događaju u 18. i 19. stoljeću. Dogodila su se tri kolonizacijska vala. Pod upravom princa Eugena Savojskog naseljeno je oko 60000 ljudi, zatim za vladavine Marije Terezije oko 50000 naseljenika i za vrijeme vlasti Josipa II doselilo se oko 30 000 Nijemaca (Župančić, 2017.). Presudni događaji koji su potakli kolonizaciju Nijemaca u režiji Austro-Ugarske monarhije svakako su potpisivanje mira u Srijemskim Karlovcima 1699. g. i povlačenje Osmanlija s prostora Slavonije, što je rezultiralo opustjelim krajevima, naseljima i vlastelinstvima. Za vrijeme i nakon Bečkog rata Slavonija je izgubila oko $80 \%$ stanovništva, a slično se još događalo za vrijeme epidemija kuge kroz povijest. Krajem 17. stoljeća cijela je Slavonija brojala 491 naseljeno mjesto, a 240 sela bilo je pusto. Ukupno je u to vrijeme Slavonija imala između 70000 i 80 000 stanovnika, a najveći gradovi, kao što su Osijek ${ }^{4}$, Požega i Brod, imali su od 600 do 800 stanovnika (Mažuran, 1988.:40-42). U 18. stoljeću počinje masovniji dolazak Nijemaca, podržan i propagiran od Austro-Ugarske, a u prvoj polovici 18. stoljeća vlastelini (Eltz, Janković, Pejačević i drugi) naseljavaju Nijemce na svoja gospodarstva kao radnu snagu. U drugoj polovici 18. st., posebno pri njegovom kraju, događa se masovnija i organizirana kolonizacija etnički raznolikog stanovništva, koji su kasnije, u vrijeme nastanka nacija, supsumirani pod zajednički etnikum Nijemci. Doseljenici dolaze iz Frankofonije, Falačke, Württemberga, Badena, Porajnja i Lotaringije, nešto manje iz Saske i slobodnih gradova-država, a najviše ih je bilo iz Švapske. ${ }^{5}$ Otuda i naziv Švabe za Nijemce, koji poprima pejorativni prizvuk, a još preciznije autori iz njihovog etničkog korpusa nazivaju ih Podunavske Švabe (Beus-Richembergh, 2010.). Nijemci doseljavaju u civilnu Slavoniju i Vojnu krajinu, gdje dolaze zemljoradnici, posebno za vrijeme vladavine Josipa II, te naseljavaju postojeća a djelomično ili potpuno opustjela sela ili osnivaju nova (Geiger, 2005.). Glavnina Nijemaca, kako o tome piše V. Geiger, došla je u Slavoniju i Srijem u drugoj polovici 19. stoljeća, ali ne iz njemačkih zemalja, nego iz prethodno koloniziranih naselja Banata, Bačke i Baranje (Geiger, 2005.). Njihovo doseljavanje u Slavoniju bilo je vrlo intenzivno, što pokazuju podaci iz 1910. godine. ${ }^{6}$ Najveća je koncentracija njemačkoga življa 1910. godine

${ }^{4}$ Nijemci u Osijeku 1792. g. osnivaju Novi grad (Neustadt) južno od Tvrđe, koji je do 1945. bio gotovo isključivo njemačko naselje. Pored velikog doprinosa Nijemaca izgradnji Osijeka, važno je istaknuti jedinstveno njemačko essekersko narječje. Osijek 70-ih g. 19. st. broji 18000 stanovnika, od toga je oko 9000 Nijemaca (Trischler, 2007.).

5 Kako navodi Z. Živaković-Kerže, gospodarske aktivnosti i razvoj tržišnog gospodarsta, što uključuje sječu šuma, razvoj industrije, gradnju željeznice, unapređenje agrarne proizvodnje, u drugoj polovici 19. st. intenzivira migracije u Slavoniju, pa i dolazak Nijemaca u većem broju. Od toga vremena, mjesta, trgovišta i gradovi na Dravi imali su pozitivan migracijski saldo. Najčešće su u njih dolazili obrtnici i trgovci (Živaković-Kerže, 2009.).

${ }^{\mathbf{6}}$ Kao polaznu točku za prikaz etnodemografskih promjena na prostoru Slavonije D. Živić uzima upravo 1910. godinu, a kao završnu 1991. godinu, kada je proveden popis stanovništva uoči ratnog raspada SFRJ i političkog konstituiranja Republike Hrvatske. Na ovom prostoru, u razdoblju od 1910. g. do 1991. g., broj se Nijemaca drastično smanjio sa 79542 na svega 1 227, ili prema udjelu s $13,5 \%$ na svega $0,1 \%$ (Živić, 1998.). 
ustanovljena u Srijemskoj županiji (61 527 ili 15,5\%), potom u Virovitičkoj županiji (29 497 ili 12,2\%), Požeškoj županiji (13 143 ili 5\%) i na području grada Osijeka (11 269 ili 35,9\%) (Beus-Richembergh, 2010.:130). Nijemci su bili najzastupljeniji u gradovima (trgovištima): Osijek, Beli Manastir, Đakovo, Vinkovci, Vukovar, Županja, Požega, Slavonski Brod, Našice, Donji Miholjac, Podravska Slatina, Virovitica, Daruvar, Pakrac, Nova Gradiška, Novska, Kutina, Garešnica, Grubišno Polje, Bjelovar te izvan Slavonije još i Zagreb (Geiger, 2005.). Gospodarski utjecaji Nijemaca na slavonsko gospodarstvo, posebno poljoprivredu, bili su izrazito razvojni i poticajni. Ima više segmenata u gospodarstvu koji su poboljšani pod utjecajem njemačkih doseljenika. Tako je stoka u Slavoniji prije dolaska Nijemaca pasla na otvorenom, što je bilo povoljno u proljeće i u jesen, da bi zbog nedostatka hrane u zimi ugibala. Dolaskom Nijemaca počinje stajski uzgoj stoke, što svakako poboljšava tu granu poljodjelstva. Drveni plug zamijenjen je željeznim, a vukli su ga konji umjesto volova, što je bilo brže i učinkovitije (Galiot-Kovačić, 2008.). Pisac A. M. Relković u djelu Satir iliti divlji čovik preporučuje poljoprivredu po uzoru na njemačku, uz kritiku rada samo do užine i pretjeranog pijanstva kod Slavonaca. Gnojidba zemlje stajskim gnojem, zamjena srpa kosom, konzerviranje voća i povrća samo su još neki od značajnih doprinosa Nijemaca slavonskom i hrvatskom gospodarstvu. Nijemci su u Hrvatskoj i Slavoniji bili brojni, sa značajnim kulturnim resursima, što je sve vodilo kulturnom i političkom organiziranju. Do Prvog svjetskog rata uglavnom se radilo o kulturnom organiziranju, prije svega u školstvu. Tako se pučka škola za doseljene Nijemce, uglavnom iz Bavarske i Württenberga, organizira 1816. godine u Retfali (osječka gradska četvrt). ${ }^{7}$ Škola prestaje $s$ radom 1944. g., kada se Nijemci zajedno s njemačkom vojskom iseljavaju iz Osijeka (Rasković, 2008.). Odjeljenja na njemačkom jeziku egzistirala su također u pučkim školama u kotarima Vinkovci, Vukovar i Županja (Rodinis, 2017.). Osim škola postojali su još tisak na njemačkom jeziku, kazališta i vjerski obredi. Počinju uskoro i politička organiziranja njemačke nacionalne zajednice. Tako je u Rumi 1913. g. osnovan Savez Nijemaca u Slavoniji i Srijemu, a u Novom Sadu je 1920. g. osnovan Kulturbund. Uloga Kulturbunda bila je promicanje njemačke kulture i jezika, da bi $s$ dolaskom nacionalsocijalista na vlast to preraslo u politički program. Do sukoba $s$ umjerenom strujom u Kulturbundu dolazi 1936. g., kada je B. Altgayer osnovao u Osijeku Kulturno i dobrotvorno udruženje Nijemaca. Kulturbund je raspušten 1941. godine, a njegovu ulogu preuzima Njemačka narodnosna skupina u NDH. Dio je Nijemaca aktivno sudjelovao u osvajačkim pohodima njemačkih postrojbi u Drugom

${ }^{7}$ U Retfali su pored Nijemaca bili brojni i Mađari. O tome piše V. Šabić i ističe da su Mađari i Nijemci činili u Retfali zasebne i relativno zatvorene zajednice, no koje su ostvarile dobre međusobne odnose, što je često podrazumijevalo i poznavanje obaju jezika ili pak uporabu zajedničkog hrvatskog jezika. Nijemci svoj jezik zovu ehtesekeriš (echt esekerisch), čisti esekerski, dakle osječki, no smatraju da postoje male razlike između njemačkog jezika u Retfali i Osijeku (Šabić, 2002.). 
svjetskom $\mathrm{ratu}^{8}$, a mali se broj njih suprotstavio politici nacionalsocijalizma. ${ }^{9}$ Pobjedom antifašističkih snaga u Europi i u bivšoj Jugoslaviji, pored suđenja ratnim zločincima, dogodio se čitav niz postupaka i procesa u kojima su dominirali osveta i revanšizam, s brojnim stradalim pripadnicima njemačke nacionalne zajednice. Stradanja Nijemaca za trajanja Drugog svjetskog rata, a još više u poraću, počinju odlukama Predsjedništva AVNOJ-a, da bi na operativnoj razini Nijemci bili planski protjerani u Austriju i Njemačku i zatvarani u logorima. Sredinom srpnja Saveznici su zatvorili granice prema Austriji, Italiji i Mađarskoj, što je onemogućilo odlazak Folksdojčera iz Jugoslavije, pa za njih slijede logori i prisilni rad (Geiger, 2018.). Osim brojčanog smanjenja Nijemaca, i to gotovo desetorostruko u odnosu na prijeratno razdoblje, za pobjednike u ratu važna je bila njemačka imovina i njezina eksproprijacija. Njemačkoj manjini u Hrvatskoj oduzeto je 20457 posjeda, površine 120977 ha (Laušić, 1991.). U vremenu raspada socijalističkih poredaka i disolucije socijalističkih i federativnih država (SFRJ, ČSSR, SSSR) došlo je do reafirmacije nacionalnih identiteta svih, a posebno do tada nešto potisnutih i/ili stigmatiziranih nacionalnih zajednica. Nijemci su u različitim državama, a svakako i u bivšoj Jugoslaviji, bili jedna od takvih nacionalnih zajednica. Noseći teret nacizma i stigmu uglavnom po toj osnovi, uz progone i protjerivanja ta je nacionalna zajednica višestruko smanjena u broju i udjelu u stanovništvu više zemalja, posebno u slučaju SFRJ i njezinih republika, sada novih država, sljednica bivše zajedničke države. Popisi stanovništva pokazuju navedene trendove i izlazak iz nepovoljnih, stigmatizirajućih okolnosti u kojima su Nijemci egzistirali u vremenu postojanja socijalističke Jugoslavije. Tako prema popisu iz 1991. g., provedenom neposredno uoči ratnih sukoba i raspada bivše države, u Hrvatskoj je registrirano ukupno 2635 Nijemaca. Već u narednom popisu stanovništva 2001. g. broj pripadnika njemačke nacionalne zajednice povećava se na 2902 osobe, da bi u posljednjem popisu stanovništva 2011. godine taj broj još povećan i iznosi ukupno $2965 .{ }^{10}$ To povećanje broja Nijemaca najviše se može povezati s izlaskom te populacije iz etnomimikrije i obnovom njemačkog nacionalnog identiteta, čemu je uz destigmatizaciju svakako pomogla i percepcija zasnovana na političkim aktivnostima Njemačke kao države koja je pomogla osamostaljenju Republike Hrvatske devedesetih godina dvadesetog stoljeća.

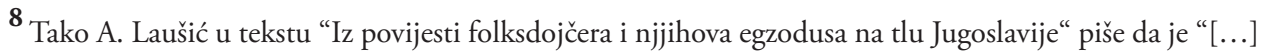
oko 35\% Folksdojčera s teritorija NDH i 60\% iz Banata činilo elitni bataljon Prinz Eugen kao sastavni dio operativne grupacije Wehrmachta" (Laušić, 1991.:186).

${ }^{9}$ Nijemci su u Hrvatskoj u toku Drugog svjetskog rata formirali 15. kolovoza 1943. g. u Slatinskom Drenovcu kod Orahovice njemačku partizansku jedinicu Ernest Thälmann. Iako malobrojna, ta jedinica imala je značajnu političku težinu kao pokazatelj otpora unutar same njemačke nacionalne zajednice i stvaranje ozračja u kojem bi trebalo izbjeći generalizaciju na cijelu naciju, što uglavnom nije uspjelo na razini političkog, kako pri kraju rata tako ni u poraću.

10 ,

Za Slavoniju i pet županija koje čine taj prostor (Virovitičko-podravska, Brodsko-posavska, Požeškoslavonska, Osječko-baranjska, Vukovarsko-srijemska) broj Nijemaca po popisima iznosi: Popis 1991. 1277, Popis 2001. - 1306 i Popis 2011. - 1087. (Popis stanovnistva 1991., Dokumentacija 889. Zagreb: Državni zavod za statistiku, 1996., Popis stanovnistva 2001. Zagreb: Državni zavod za statistiku, 2002. Popis stanovništva 2011., Zagreb: www. Državni zavod za statistiku, 2013.). 


\section{Suživot, nacionalni identitet, stigma}

Suživot je povezan s multikulturalizmom, a na početku 21. stoljeća u Njemačkoj je plasirana konstatacija kako je multikulturalizam mrtav. ${ }^{11}$ Kakva je onda perspektiva suživota i je li moguć suživot ljudi različitih (sub)identitetskih obilježja, posebno nacionalne pripadnosti, koja se uglavnom tretira kao identitet svih identiteta, svojevrsni nadidentitet? Kakav je bio suživot tokom stoljeća i kako su ratovi, posebno na primjeru Nijemaca u Slavoniji, utjecali na njegovu destrukciju i rekonstrukciju? Pođimo od multikulturalizma da bismo došli do određenja suživota (multietničke koegzistencije) i svih aporija oko njegove implementacije u primarnom socijalnom ambijentu lokalnih zajednica koje imaju multietničku/multinacionalnu dimenziju. Multikulturalizam ima više značenja, od teorijskih, ideoloških do političkih (Mesić, 2012.), a temelji te paradigme na svim navedenim razinama impliciraju uključivanje i afirmiranje rodnih, rasnih, kulturnih, vjerskih, nacionalnih i drugih različitosti (Vujačić, 2010.). Multikulturalizam se referira na različitosti kultura u društvu, a razlikuje se u SAD-u i u Europi, kao i između pojedinih država Europe (Abercrombie, Hill i Turner, 2008.). Temeljno polazište odnosi se na teorijski i političkooperativni koncept i politiku uređivanja međunacionalnih odnosa u multietničkim/multinacionalnim društvima. Pritom u društvima s političkim oblikom nacije glavni obrazac čini odnos države prema useljenicima i etničkim zajednicama, a u društvima s etničkim oblikom nacije najvažnije je pitanje $s$ aspekta multikulturalizma uređivanje odnosa između većinske nacije i nacionalnih manjina. Liberalni koncept uređivanja tih odnosa, primjeren uglavnom za politički (građanski) oblik nacije, prednost daje sustavu liberalnih zakona (Barry, 2006.), koji, prema ovom autoru, stvara manje problema od politike različitosti koje zagovara multikulturalizam. Za razliku od njega, zagovaratelj multikulturalizma W. Kymlicka ističe važnost grupne pripadnosti, posebno etničke/nacionalne (Kymlicka, 2003.), jer takve zajednice s kulturnim kompleksom daju smisao pojedincima, sigurnost, toplinu, sve ono što ne može dati politički sustav samo s institucionalnom regulativom društvenih odnosa. I dok na teorijskoj i institucionalnoj razini postoji prijepor oko modela uređivanja međunacionalnih odnosa, u lokalnim zajednicama, selima, gradovima, regijama, funkcioniraju različiti oblici međunacionalne koegzistencije (suživota) između pripadnika različitih etničkih/nacionalnih zajednica i onih koji nisu opredijeljeni prema tim kriterijima. Što čini sadržaj suživota i kakvi su teorijski refleksi navedenog pojma? Lokalna zajednica pretpostavka je egzistiranja ljudi, pa onda i ljudi različitih kolektivnih pripadnosti, uključujući nacionalne. Tek su tu mogući neposredni ljudski kontakti, a neki autori smatraju da se za naciju može koristiti termin zajednica, ali samo ako se doda pridjev zamišljena (Anderson, 1990.). Moderno se društvo ne može obuhvatiti neposrednim iskustvom (Adorno i Horkheimer, 1980.),

${ }^{11}$ Na skupu mladih članova CDU-a 2010. g. njemačka je kancelarka Angela Merkel izjavila da je multikulturalizam mrtav. Kritika je usmjerena na samo supostojanje Nijemaca i drugih u Njemačkoj, ponajprije vrlo brojnih Turaka. Kancelarka je dodala da je kriv pristup prema kojem bi Turci i Nijemci trebali živjeti jedni pored drugih, već bi oni koji žele sudjelovati u njemačkom društvu trebali znati njemački jezik. 
pa se stoga empirijski suživot može promatrati upravo na razini lokalne zajednice. Lokalnu zajednicu čini nekoliko sastavnica, s postojanjem zajedničke svijesti o jedinstvu i posebnosti takve zajednice, a čine ju četiri elementa: ljudi, prostor, potrebe i djelatnosti (Pusić, 1963.). Socijalna konstrukcija i kontinuirana restrukturacija lokalnih zajednica koje imaju multietnički/multinacionalni sastav čini ono što se može nazvati suživot. Pitanja suživota s Hrvatima, Srbima, Mađarima i drugima u Slavoniji prisutna su kod Nijemaca od prvih dolazaka do socijalističkog poretka, gdje se to posebno aktualizira. Problematiziranje suživota na prostorima bivše Jugoslavije aktualizirano je u procesu njezina raspada. Dotadašnja multinacionalna koegzistencija pod kontrolom Partije, iako s tradicijom znatno dužom od socijalističkog poretka, bila je na političkoj razini sažeta u sintagmi "bratstvo i jedinstvo naših naroda i narodnosti". Raspad te političke paradigme u ratnim sukobima devedesetih aktualizirao je propitivanje multietničke koegzistencije, s temeljnim pitanjem o tome zašto je potpuno ili djelomično došlo do raspada suživota i je li moguća njegova obnova. Na temu suživota J. Županov piše: "Suživot se sociološki može odrediti kao splet solidarističkih mreža primarnih (neslužbenih) društvenih odnosa među pripadnicima različitih etnija na mikrosocijalnoj razini. To nije neka integrirana mreža, ona više nalikuje arhipelagu mrežnih otoka i džepova” (Županov, 1998.:214). Upravo zahvaljujući tome ratni sukobi devedesetih godina prošlog stoljeća i raspad SFRJ nisu do kraja pokidali takve mreže, ali su ih značajno pa i teško razorili. Slično se je događalo i za vrijeme Drugog svjetskog rata, što je posebno odredilo sudbinu Nijemaca. Dugotrajno trajanje suživota, posebno kod srednje i starije generacije, i komunikacijsko sjećanje aktera omogućuju njegovu postupnu iako vrlo sporu obnovu. Najmlađi pripadnici društva, koji su tada bili djeca ili se nisu ni rodili, socijalizirani su u drugačijem ambijentu, s dominantnim etnocentrizmom i etnonacionalizmom, pa su odnosi prema drugim nacijama kod njih, u Hrvatskoj posebno na relaciji Hrvati - Srbi, znatno drugačiji, s više isključivosti (Babić, 2008.). Na temelju empirijskih istraživanja o destrukciji i mogućoj pa u nukleusima i zbiljskoj rekonstrukciji multinacionalnih lokalnih zajednica u Hrvatskoj, suživot se definira kao "[...] normativna i funkcionalna umreženost i uzajamna tolerancija različitih makro/mikrogrupnih subidentitetskih obilježja različitih socijalnih aktera u lokalnim zajednicama” (Babić, 2010.:85). Normativna i funkcionalna integracija, koje uključuju simboličku sferu i kolektivni imaginarij nacionalnih zajednica (normativna) i međusobnu suradnju u gospodarskim djelatnostima i svakodnevici (funkcionalna), čine glavne moduse uključivanja i međusobne socijalne interakcije pripadnika različitih nacionalnih zajednica, što rezultira socijalnom konstrukcijom mreže primarnih socijalnih veza na lokalnoj razini (suživot). Za suživot su potrebni etnički Drugi, a tek u socijalnoj interakciji s etnički/nacionalno različitima moguće je razmišljati i osvijestiti vlastiti kolektivni identitet toga tipa, pa je etnički identitet značajan kao međuetnička razlika. Upravo postojanje etničkog stranca omogućuje izoštravanje slike vlastitog kolektivnog identiteta, ali i pojačavanje emocija prema njemu, sve do najveće netrpeljivosti i slijepe mržnje, što se instrumentalizira po potrebi o kojoj odlučuju središta društvene moći (Vlaisavljević, 2018.). Upravo od ekstenzije etnič$\mathrm{kog} /$ nacionalnog identiteta zavisi suradnja s drugima, a time i koegzistencija s njima 
ili suživot. Prekomjernim jačanjem toga identiteta, što se čini na ideologijskoj i političkoj razini u vrijeme intenzivnijih konflikata s drugima, a može završiti u ratnim sukobima, izrazito se smanjuju obujmi ostalih čovjekovih (sub)identiteta, a time biva dokinut zbiljski identitet čovjeka pojedinca (Devereux, 1990.). To postaje sverazorno po prethodno socijalno a u određenoj mjeri i politički konstruiranu, desetljećima pa i stoljećima obnavljanu i dograđivanu mrežu primarnih socijalnih odnosa (susjedstvo, prijateljstvo, kumstvo, bračne i generacijske veze), a in ultima linea i za samu nacionalnu zajednicu u kojoj je proizvedena i različitim sredstvima, od političkih do medijskih, proširena etnička mržnja. Iako se često kroz prizmu pojedinačnih postupaka mjeri nacija kao takva, pa se pojedinci iz druge nacionalne zajednice prekomjerno stigmatiziraju, kao i čitava ta zajednica uostalom, događa se i obrnuto, pa se iz pojedinčevih postupaka izvodi zaključak da je on veći čovjek od onih iz redova naše zajednice. No pritom je važno da pojedinačni postupci i odnosi ne mogu ukidati ili preformulirati odnose između nacionalnih zajednica (Vlaisavljević, 2018.). Takve odnose mogu narušavati oblici stigmatizacije pojedinaca ili čitavih skupina u društvu, a to se i zbiljski događa, naročito kod nekih oblika stigme, posebno onih politički insceniranih. Za stigmu u Rječniku sociologije nalazimo da je "stigma [...] društveni biljeg kojim se diskreditira pojedinca ili skupinu. Postoje stigma tijela (npr. tjelesne mane i deformacije), stigma karaktera (npr. homoseksualnost) i društvenih kolektiva (npr. rase ili plemena)" (Abercrombie, Hill i Turner, 2008.:367). Neke značajke pojedinih osoba mogu za njih predstavljati rizik od neprihvaćanja okoline, pa se u tim slučajevima može govoriti o stigmi. Autor knjige o stigmi E. Goffman definirao je razliku između aktualnog i virtualnog socijalnog identiteta. Prema njemu, stigma je oznaka za procjep između tih dvaju identiteta (Goffman, 1968.). Kako piše S. Vrcan, stigmatizacija se manifestira u trima glavnim oblicima. Prvi je stigmatizacija pojedinaca zbog nekih njihovih osobnih značajki (npr. "ćoro"- problem vida, "mulac"- izvanbračno dijete i sl.). Kao drugi oblik navodi se kolektivna stigmatizacija onih skupina koje odstupaju od društvene normalnosti ("vlaji", "purgeri", "tovari" i sl.). I dok su prva dva oblika folklorna, treći je oblik stigmatizacije politički insceniran od samog državnog aparata (npr. jugoslavenski slučaj 1948. g. i obračun sa "staljinistima", 1971. i "proljećari" i sl.), (Vrcan, 2003.). Navedeni sociolog smatra da je politička stigmatizacija u funkciji ostvarenja onih ciljeva koji se ne mogu postići demokratskim sredstvima (Vrcan, 2003.). Stigmatizacija Folksdojčera događa se u poslijeratnom razdoblju socijalističke Jugoslavije, u totalitarnom, a nakon pedesetih godina dvadesetog stoljeća autoritarnom sustavu vlasti. Ciljevi nove vlasti odnosili su se na progon i izoliranje Folksdojčera te oduzimanje njihove imovine. Stigma se proizvodi u urbanim centrima u kojima je koncentrirana društvena, posebno politička moć, a najbolji su sociopsihološki ambijent za transmisiju stigme sredine koje su kulturno i civilizacijski inferiorne, s patrijarhalnim obrascima u međuljudskim odnosima (Blažević, 2003.). Stigma kakva je pogodila Nijemce u razdoblju nakon završetka Drugog svjetskog rata imala je izrazitu snagu, što se može objasniti, između ostaloga, dugotrajno egzistirajućim obrascima kolektivističkih formi života i mišljenja (Bogdanović, 2003.), ali još više činjenicom njemačkog osvajačkog rata, okupacije i teških posljedica nacionalsocijalističke politike 
u cjelini. Destigmatizacija s političke razine posebno je značajna kako za pripadnike stigmatizirane zajednice tako i za inkluzivnost društva i uspostavljanje društvenih odnosa koji se temelje na toleranciji, poštivanju i zaštiti ljudskih, građanskih i manjinskih prava. Za zajednicu je važan kontinuitet i modalitet koji to omogućuje, a etnička zajednica mora za svoje fizičko tijelo imati adekvatan simbolički sadržaj (Vlaisavljević, 2018.). Slično vrijedi i za koegzistenciju više takvih zajednica, njihovu identifikaciju u društvu s drugim sličnim zajednicama kao i njihovu međusobnu socijalnu interakciju i komunikaciju. Destigmatizacija znatno olakšava reafirmaciju nacionalnog identiteta, a Nijemci u Hrvatskoj (Slavoniji) nakon disolucije jugoslavenske države i tranzicije iz socijalizma u tržišni tip gospodarstva i politički pluralizam izašli su, kao malobrojna zajednica, iz dugotrajne etnomimikrije. Iako je njemačka nacionalna zajednica u Slavoniji i Hrvatskoj u specifičnoj situaciji, pitanja su nacionalnog identiteta u vremenu globalizacije i raspada socijalističkih poredaka postala važna uporišna točka za kolektive i pojedince u novom vremenu. Nacionalni identitet figurira kao dominantni kolektivni identitet (Smith, 2008.), kao svojevrsni nadidentitet koji daje uporište pojedincima i čitavim zajednicama. Tamo gdje egzistira etnički oblik nacije, a što vrijedi za Istočnu Europu i Nijemce kao naciju ${ }^{12}$, nacionalni je identitet doživio punu reafirmaciju sa svim, često različitim i proturječnim, konotacijama i zbiljskim događanjima koja su s tim korespondirala.

\section{Empirijsko istraživanje: Nijemci u Slavoniji između stigmatizacije, destigmatizacije i reafirmacije nacionalnog identiteta (intervjui)}

\subsection{Metodologija}

Istraživanje pripadnika njemačke nacionalne zajednice u Baranji i gradu Osijeku provedeno je 2013. i 2019. godine. ${ }^{13}$ Kontakti s ispitanicima uspostavljeni su posredstvom u samoj zajednici aktivnih članova te nacionalne manjine, što je omogućilo kvalitetnije intervjuiranje i psihološki olakšalo ulazak u lokalne zajednice u kojima je intervjuiranje provedeno. Ukupno je 2013. g. u Belom Manastiru intervjuirano 18 pripadnika njemačke nacionalne zajednice, od toga 13 muškaraca i pet žena. U Osijeku je 2019. g. intervjuirano šest osoba, od toga pet muškaraca i jedna žena, ukupno 24 osobe iz korpusa te nacionalne zajednice. Na pitanja u intervjuima ispitanici su odgovarali između trideset i četrdeset minuta, a korišteni su polustrukturirani intervjui sastavljeni

\footnotetext{
12 Kako o tome piše H. Plessner, interpretrirajući etnogenezu njemačke nacije, Nijemci su zakašnjela nacija (Plessner, 1997.), koja nije, poput nekih drugih naroda na Zapadu, izgradila državu u vremenu prosvjetiteljstva, a njezine državne granice nisu istovjetne s granicama etnije. To je rezultiralo idejom ujedinjenja Nijemaca u jednu državu, na čemu je, između ostaloga, utemeljena politika nacionalsocijalizma. 13 Iako smo nakon provedenih intervjua u Belom Manastiru pokušali intervjuirati Nijemce u Osijeku, iz određenih organizacijskih razloga to nismo tada uspjeli, pa smo to učinili nekoliko godina kasnije. Kako su intervjui koncipirani tako da se odnose najvećim dijelom na povijesno pamćenje te nacionalne zajednice, smatramo da vremenski pomak nije bitnije utjecao na rezultate istraživanja.
} 
od osamnaest pitanja. U intervjuima su korištena različita pitanja, koja se mogu supsumirati u nekoliko podcjelina, od prihvata i suživota s domicilnim stanovništvom, problema asimilacije i očuvanja nacionalnog identiteta preko uloge Folksdojčera u Drugom svjetskom ratu te stigmatizacije Nijemaca u ratnom i poslijeratnom razdoblju do reafirmacije njemačkog nacionalnog identiteta i destigmatizacije te zajednice u vremenu nastanka samostalne hrvatske države. Uvodni dio intervjua odnosio se na sjećanje/pamćenje Podunavskih Švaba i poznavanje prošlosti njihovih predaka u Slavoniji i Baranji. Uslijedila su pitanja o prihvatu Nijemaca u novom zavičaju te o njihovom kulturnom i gospodarskom doprinosu destinacijama prihvata i prebivališta. Koliko su po dolasku, a i kasnije, Nijemci sudjelovali u etnički mješovitim brakovima i s kojim su pripadnicima od ovdje brojnijih nacija (Hrvati, Srbi, Mađari) najčešće stupali u takve brakove? Jezik je važno obilježje nacionalnog identiteta. ${ }^{14}$ Koliko su Nijemci kroz cjelokupno vrijeme od doseljavanja naovamo očuvali njemački jezik te koliko ih u vremenu provođenja intervjua govori i piše na njemačkom jeziku? Kako su pripadnici ove nacionalne zajednice organizirani u Osijeku ${ }^{15}$ i okolici te kako su zadovoljni odnosom hrvatske države prema njima kao i suradnjom i pomoći od Njemačke? Nijemci su ovdje poznati pod imenom Podunavske Švabe. Kako intervjuirani i njihovi sunarodnjaci reagiraju na to ime i jesu li imali kakvih neugodnih iskustava kao Nijemci i ako da, kako je se to manifestiralo? Upitani su dalje kakva je bila uloga Nijemaca neposredno pred Drugi svjetski rat i po dolasku njemačke vojske i koliko je time narušen suživot s pripadnicima drugih nacija na ovom prostoru. Nakon završetka Drugog svjetskog rata Nijemci su bili obilježena zajednica, čiji je znatan dio stradao na samom kraju rata i u neposredno poslijeratnom razdoblju. Sudionici intervjua upitani su što znaju o tome, iz vlastitih sjećanja ili sjećanja njihovih susjeda, prijatelja ili rođaka. Dalje, kako iz ove perspektive ocjenjuju odnos Titovog režima prema njemačkoj zajednici i kakve su se promjene u odnosu prema Nijemcima dogodile devedesetih, uspostavom Republike Hrvatske? Kao sociodemografske varijable u intervjuima su korištene: nacionalnost, spol, dob, mjesto prebivališta, na što su ispitanici dali pristanak prije samog intervjuiranja. Iako smo nastojali intervjuirati podjednak broj muškaraca i žena, odaziv je žena bio znatno slabiji, pa odatle disproporcija u samom uzorku.

${ }^{14}$ U sklopu upoznavanja svojih sunarodnjaka, iz Leipziga i Freiburga dolazili su 1933. i 1934. godine studenti njemačkih sveučilišta u Slavoniju. Njihovo zapažanje o očuvanju njemačkog nacionalnog identiteta svodi se na uočenu priličnu pasivnost, pa i uznapredovalu kroatizaciju Nijemaca. Kako su u selima i manjim mjestima elitu činili župnik, učitelj i bilježnik, a ta su mjesta držali Hrvati ili Srbi, razumljiva je apatija Nijemaca. Nije nadalje bilo bogoslužja na njemačkom jeziku. U školama nije bilo dovoljno kadrova za njemački jezik, a roditelji nisu bili dovoljno motivirani da šalju djecu u njemačke škole (Leček, 2017.). 15

5 Nijemci i Austrijanci značajno su doprinijeli kulturnom, gospodarskom i drugom razvoju grada Osijeka, a predstavnici grada odužili su im se imenovanjem ulica prema znamenitim osobama njemačkog i austrijskog podrijetla. Kako navodi Z. Živaković-Kerže, od imenovanja ulica u Osijeku, provedenog 1993. godine, ukupno 15 ulica nosi naziv istaknutih osoba austrijskog ili njemačkog podrijetla. Među njima su npr. ulica kustosa i direktora osječkog muzeja Josipa Bösendorfera, ulica hrvatskog melografa Franje Kuhača, ulica đakovačkog i srijemskog biskupa Josipa Jurja Strossmayera, ulica mirotvorca Josipa Reihla-Kira i drugih (Živaković-Kerže, 2018.). 
Što se tiče dobnih skupina, najviše je onih starije i nešto manje srednje dobi, što je bio cilj istraživača, s obzirom na duže pamćenje/sjećanje ispitanika, od kojih je manji dio bio u mogućnosti neposredno svjedočiti, a ostali su govorili kao sudionici komunikacijskog sjećanja/pamćenja ove nacionalne zajednice. Predstavnik njemačke nacionalne zajednice u Belom Manastiru i Osijeku informirao je svakog sudionika intervjua pojedinačno o istraživanju, ustanovi koja provodi istraživanje (Institut za migracije i narodnosti, Zagreb) te istraživačima, a pripadnici njemačke nacionalne manjine dali su pristanak na sudjelovanje $\mathrm{u}$ istraživanju.

\subsection{Doseljavanje Nijemaca u Slavoniju, prihvat i suživot}

Različiti su uzroci i motivi doseljavanja pripadnika neke populacije u nove prostore, a migracije su u svojoj temeljnoj podjeli dobrovoljne i nedobrovoljne (R. Heberle, u: Mesić, 1992.). Nijemci koji se analiziraju u ovom tekstu segment su dobrovoljnih migranata, a temeljni je motiv gospodarski i egzistencijalni. Naseljavanje opustjelih krajeva nakon odlaska Osmanlija s ciljem osiguranja egzistencije i poboljšanja životnog standarda glavni su motivi ove populacije u procesu migriranja u Slavoniju, Hrvatsku i prostore bivše Jugoslavije. Pritom, osim individualnih motiva, migracije Nijemaca (i ostalih kao što su Česi, Slovaci, Mađari), segment su kolonizacije koju je u novim okolnostima provodila Austro-Ugarska. Po dolasku se nameću problemi komunikacije i prihvata useljenika s domicilnim stanovništvom, a pitanja suživota, pored gospodarske integracije, bila su važna za njemačku populaciju prilikom dolaska u Slavoniju. Suočavanje s drugačijim kulturnim i gospodarskim okolnostima te različitim etničkim zajednicama bio je izazov kako za doseljeno tako i za domicilno stanovništvo. Koliko intervjuirani Nijemci znaju o doseljavanju svojih predaka i njihovoj integraciji u lokalne zajednice i koliko je komunikacijsko sjećanje još uvijek vitalno u vremenu provođenja intervjua?

Doselio sam se u Osijek, esekerski jezik se govorio ovdje, fonetski, hochdeutsch (to je službeni njemački jezik). O doseljavanju Nijemaca ovdje postoje izreke, pa je se reklo, prvima smrt, drugima bijeda (glad, poplave), trećima kruh. Dakle, tek treća generacija bere plodove seljenja u novi zavičaj. Bečka vlast je naselila prve Nijemce u Osijeku i okolici, njoj trebaju vojnici, porezni obveznici. Zemljište je bilo močvarno. Kasnije se radi mreža kanala, što je poboljšalo uvjete za poljoprivredu. Turci su krajem 17. st. otišli [...] posjed Belje se koristi za poljoprivrednu proizvodnju [...] Princ Eugen Savojski je dobio imanje u južnoj Baranji od cara Leopolda I, zemlja je tu kao potencijal [...] Habsburzi [...] zovu Nijemce iz Bavarske i drugih dijelova Njemačke [...] Kmetovi iz Bavarske su dolazili ovdje oslobodeni kmetstva a bez zemlje. Ovdje im se nudi oslobodenje od kmetstva uz zemlju koja je njihov novi početak. Jedino je Dunav bio prometnica za dolazak [...] išli su ladama, Apatin je bio luka prijema. U novooslobodenim krajevima vojska organizira život [...] nije bilo civilne vlasti (Nijemac, muškarac, 82 g., Čeminac). 
Intervjuirani pripadnik njemačke nacionalne zajednice iznosi višedimenzionalnu optiku dolaska i prvih aktivnosti Nijemaca, koja demitologizira svaku naraciju o brzom i lakom uspjehu, što često prati migrantsku literaturu, a još više usmenu predaju (komunikacijsko sjećanje). Tek naredne generacije beru plodove useljavanja i poboljšavaju životni standard, dok su pioniri u teškom položaju i izloženi velikim naporima u izgradnji gazdinstava i ukupne egzistencije svojih obitelji. Uloga države u naseljavanju Podunavskih Švaba bila je presudni činilac u migracijama. O problemima s kojima su se doseljenici susretali te ulozi države u migracijama, u komunikacijskom sjećanju u narednom intervjuu saznajemo:

Najstariji preci sunarodnjaka stigli su ovdje 1764. g. Moj predak je došao u Apatin. 1825. g. a jedan od njegove djece je preselio u Osijek. Naša je obitelj bila istjerana. Planska kolonizacija [...] ja to nisam imao skim pričati. Ja sam rastao sa Slavoncima, pa to nisu bile teme. Od kasnijih dogadaja, Nijemci su stradali nakon Drugog svjetskog rata pa tata nije volio komuniste (Nijemac, muškarac, 70 g., Osijek).

Naredni intervjuirani ističe: Ne znam ništa o doseljavanju. Malo smo pričali o tome (Nijemac, muškarac, 69 g., Nova Bukovica). Ima i onih koji nisu uopće upoznati s doseljavanjem predaka, što je vjerojatno ovisilo o udjelu njemačkog stanovništva u pojedinim lokalnim zajednicama, ali ne treba isključiti ni asimilaciju i odsustvo unutarobiteljskih i susjedskih razgovora o tome, uslijed čega je naracija o doseljavanju postupno ignorirana i iščezavala iz povijesnog pamćenja ove nacionalne zajednice. Tek nakon određenog broja i udjela neke populacije u naselju i okolici moguća je intenzivnija unutarnacionalna komunikacija kao pretpostavka komunikacijskog sjećanja kojim se prenose informacije o počecima nacionalne zajednice na nekom prostoru.

Kršten sam kao Švabo Klenk [...] Nijemci su došli prije Turaka, nisu došli u 18. st., nego prije toga, bili su majstori, trgovci, kovači, kolari još u tursko vrijeme. Otac je Hrvat a mama je Švabica iz Bačke Palanke, druga i treća generacija. Klenk [...] prezime moje mame [...], otišla je u Brazil, otišli su organizirano. Druga kolonizacija Švaba, kolonija Entre Rios. Otac je nastradao. Do šeste godine nisam znao hrvatski, govorio sam samo njemački. (Nijemac, muškarac, 73 g., Osijek).

Njemački se jezik, prema intervjuiranom pripadniku njemačke zajednice, govorio u obiteljima, pa su tek s polaskom u školu neki pripadnici ove zajednice učili jezik etničke većine i druge jezike. I u narednom intervjuu navode se razlozi dolaska Nijemaca u Slavoniju, naseljavanje prostora i značaj Eugena Savojskog za kolonizaciju.

Nijemci nisu ovdje došli kao osvajači, nego kao sudionici kolonizacije. Eugen Savojski je prostor naseljavao migrantima iz njemačkih pokrajina, nakon odlaska Turaka iz Slavonije. Svrha kolonizacije bilo je oživljavanje prostora koji je ostao relativno nenaseljen. Migracije su išle Dunavom, Apatin je bio luka prihvata (Nijemac, muškarac, 74 g., Beli Manastir). 
Sljedeća sudionica intervjua navodi: Moj tata je Nijemac, a njegovi su ovdje stigli za vrijeme vladavine Marije Terezije. Doselili su u Bansku Kosu. Djed je imao tri brata, imam rodbine u Apatinu i Bezdanu. (Njemica, žena, 58 g., Beli Manastir).

Početak je bio težak, a kolonisti su stimulirani da krenu u poljoprivrednu proizvodnju u koju su unijeli svoja dotadašnja znanja i tehnološka dostignuća.

U novooslobođenim krajevima vojska organizira život [...] nije bilo civilne vlasti [...] Čeminac je $18 \mathrm{~km}$ udaljen, jedini na brežuljku [...] Ti ljudi su dobili tri vreće žita, nešto kukuruza. Čeminac ... vrlo uređeno selo. Željezni plugovi su došli sa Nijemcima, stočarstvo se razvija [...] nakon 1918. Čeminac nije samo njemačko selo (Nijemac, muškarac, 82. g., Čeminac).

Naredni intervju, pored sjećanja na doseljavanje, ističe i odnose u obitelji koja je bila multinacionalna. Ženidbene veze bile su unutargrupne uglavnom tamo gdje je bilo više Nijemaca.

Mama je rodena u Krapinskim Toplicama. Mamini su došli u Tenjski Antunovac u kuću jednog Srbina. Najmladi je bio u partizanima. Godine 1945. je završio rat, došao je vlasnik kuće i onda je grupa Srba iz Tenje optužila neke od Nijemaca da su sakrili puške [...] Mama i tata su se oženili 1949. Otac se osjećao Nijemcem, pisao se Roth, a mi ostali Rot. Ja sam pola Nijemac pola Hrvat. Nisam nikad imao problema u komunikaciji s ljudima i vlastima [...] Moj otac je postao poslovoda u firmi. Otac je pokušao pričati njemački. Rodbina je otišla 1944. godine prema Njemačkoj. Seoske sredine imaju svoje specifičnosti, veliko selo [...] izbor partnera je bio najčesće iz svoje etničke zajednice, mala sela ne, bila su više izmiješana. Tokom prva dva stoljeća njemačkog življenja ovdje, standard se stabilizira. Prednja soba [...] gostinska, tu se sastaje rodbina, prijatelji [...] grad je drugo [...] tu nema takvog utjecaja zavičaja, veća je individualnost. (Nijemac, muškarac, 63 g., Belišće).

Nijemci su dobro surađivali s pripadnicima drugih nacionalnih zajednica, a u dosta slučajeva suživot je bio na visokoj razini. $\mathrm{O}$ tome u intervjuu saznajemo:

Po dolasku u Slavoniju Nijemci se uključuju u život sa drugima. U Baranji je se govorilo tri jezika i to, hrvatski (srpski), madarski i njemački. Suživot je bio kvalitetan, onako kako bi čovjek poželio da bude, da živi s komšijama. Pravoslavna crkva je bila u Švapskom sokaku. U vrijeme pravoslavne krsne slave, Švabe su uredili sokak kukuruzovinom, išli su čstitati Srbima i govorili su njihovim jezikom. Inače, uvijek se govorilo jezikom domaćina, kod Madara madarskim, kod Nijemaca njemačkim. (Nijemac, muškarac, 74 g., Beli Manastir).

Sjećanje/pamćenje Nijemaca koji su sudjelovali u ovom intervjuiranju sadrži informacije o dolasku i prijemu njihovih predaka u Slavoniju. Intervjuirani su Nijemci 
u primarnosocijalizacijskom ambijentu, u obitelji prije svih, saznali dosta o povijesti doseljavanja svojih predaka u užem smislu i sunarodnjaka u cjelini. Slike u glavama (Roth, 2000.) intervjuiranih sadrže svu slojevitost i realizam u prikazu obiteljske, susjedske i etničke prošlosti. Tako se ističe težak početak, problemi s kojima su se susretali prvi doseljenici, koji su, kako navodi jedan sugovornik, često žrtvovali zdravlje, a poneki i život za bolju budućnost narednih generacija. Olakotna okolnost u doseljavanju Nijemaca bio je plan države Austro-Ugarske da naseli prostore koje su nakon vojnih poraza napustili Osmanlije. Država i veleposjednici gospodarskim su resursima pomagali doseljenike, dodjelom zemlje za obradu kao i poljoprivrednih proizvoda koji su trebali omogućiti prehranu do njihove prve žetve. Uz bivše kmetove, koji dolaskom u nove prostore izlaze iz kmetskog statusa, doseljenici su također i obrtnici, koji donose tehničku kulturu koja je znatno razvijenija od domicilne. Obrtnici su svojim tehnološkim doprinosima utjecali na poboljšanje poljoprivrede kao glavne djelatnosti, posebno korištenjem željeznog umjesto drvenog oruđa za rad. Komunikacija s domicilnim stanovništvom imala je uglavnom u početnom razdoblju naseljavanja Nijemaca funkcionalnu dimenziju i odnosila se najviše na posao i razmjenu proizvoda, da bi u kasnijem razdoblju sve veću dimenziju u socijalnoj interakciji zauzimali socijalni odnosi koji uspostavljaju trajnije zajednice (prijateljstvo, susjedstvo, bračne veze, kumstvo). Njemački jezik govori se u obitelji da bi tek u školskoj dobi mladi pripadnici njemačke zajednice upoznavali i druge jezike, što posebno vrijedi za razdoblje prvih doseljenika.

\subsection{Stigma njemačke nacionalne zajednice u Drugom svjetskom ratu i u socijalizmu}

Pripadnici njemačke nacionalne zajednice nose kolektivnu stigmu koja svoje ishodište ima u Drugom svjetskom ratu, njemačkom nacionalsocijalizmu i ulozi Podunavskih Švaba u tim događajima. Tome je, uz navedeno, pridonijela politička optika nove partizanske vlasti, a kasnije, nakon konstituiranja Druge Jugoslavije, njezina poslijeratna državna politika. Neke odluke predsjedništva AVNOJ-a usmjerile su događaje ${ }^{16}$ u kojima su Nijemci u velikoj većini predodređeni za kasnija stradanja. Sve se to nastavlja i u socijalizmu, posebno u prvim poslijeratnim godinama. To je rezultiralo strahom kod onih malobrojnih Nijemaca koji su ostali na prostorima bivše jugoslavenske države, a etnomimikrija je bila svojevrsni, iako nepotpun, izlaz iz procesa stigmatizacije. Nije bilo dovoljno samo promijeniti nacionalnost, ostalo je ime, prezime, porijeklo i sve ono što čini pogodan teren za stigmatizaciju pripadnika neke, u ovom slučaju njemačke zajednice. Akteri intervjua manjim su dijelom sudionici tih događaja vezanih za Drugi svjetski rat, a svi intervjuirani živjeli su u vremenu i poretku u kojem se je

16 Predsjedništvo AVNOJ-a 21. studenoga 1944. g. donijelo je "Odluku o prijelazu u državno vlasništvo neprijateljske imovine, o državnoj upravi nad imovinom neprisutnih osoba i o sekvestru nad imovinom koju su okupatorske vlasti prisilno otuđile" (Geiger, Vladimir "Josip Broz Tito i sudbina jugoslavenskih Nijemaca", Zagreb: Časopis za suvremenu povijest, Vol. 40, No. 3, 2008, str. 789-818. 
Nijemce, posebno do 60-ih godina dvadesetog stoljeća i otvaranja granica, prikazivalo kao okupatore i zločince, što za dio pripadnika ove nacionalne zajednice svakako vrijedi kao egzaktna konstatacija. Situacija se podosta mijenja, a Nijemci kao nacija i Zapadna Njemačka kao država tih godina postaju simboli radišnosti, gospodarskog napretka i uređenosti. O iseljavanju, poslijeratnim logorima, ubojstvima i nepovoljnom sociopsihološkom ozračju vezano za njemačku nacionalnu zajednicu saznajemo od intervjuiranog Nijemca koji je kao dijete proživio neke od tih ratnih i poslijeratnih događanja.

U intervjuu saznajemo: U Baranji [...] Kozarac, Grabovac, Čeminac i Novi Čeminac, to su bila čisto njemačka sela [...] još u toku drugog svjetskog rata, 1944. g. organizirano je iseljavanje Nijemaca iz Baranje, Osijeka u Njemačku. Gakovo konclogor [...] Valpovo (žica) i Krndija (radni logor), logori. Odluka AVNOJ-a ima tri točke od kojih je samo jedna točka objavljena, ona o konfiskaciji. Druga točka je protjerivanje, treća [...] logori [...] 11. 5. 1945. masovno su se kupili svi Švabe [...] tri dana su stajali u Dravogradu. Englezi ne prihvaćaju Švabe, već ih vraćaju prema Valpovu. Mi smo bili madarski državljani 1941. g. [...] Kreće kolona užasa, bijede, nemoćnih ljudi. Tko god ne može dalje, ubijen je. Najprije smo došli u Krndiju. Vraćamo se preko Bizovca do Valpova i dolazimo u žicu, to je bila njemačka destinacija za rad, 1941. do 1945. Njemačka narodna skupina, ti su ljudi tamo pomagali. Logor je raspušten 29. 4. 1946. Svi mi Nijemci smo 11. 5. 1945. obukli zimsku odjeću i obuću. Partizanska siročad je dovedena u naše kuće. Kad smo se vratili nismo išli svojim kućama. Otac mi je umro od tifusa 6. 3. 1946., umrlo je tada 80 ljudi od tifusa"(Nijemac, muškarac, 82 g., Čeminac).

Političke odluke novih vlasti odredile su perspektivu njemačke nacionalne zajednice, koja je završila logorima i protjerivanjem Folksdojčera te naseljavanjem kolonizatora iz pasivnih krajeva tadašnje jugoslavenske države. O zanimanju i oduševljenju za politiku njemačkog Reicha, sudjelovanju u Kulturbundu i SS trupama saznajemo iz narednog intervjua.

Bila je 1941. g, išla je velika propaganda za Njemačku. Puno njih je otišlo tada u SS trupe dobrovoljno. Kulturbund nije bio samo kulturni centar, već i propagandni, nacionalsocijalizam je bio u temelju te propagande. Mi smo se malo udaljili od njih, ja sam nedjeljom prije podne morao ići u crkvu. Na ulici marširaju Hitlerjugend ${ }^{17}$, a meni je bilo krivo što moram ići u crkvu. Ja nisam smio, jer sam iz drugačije porodice. I stariji su marširali. Imali su kukasti križ. (Nijemac, muškarac, 80 g., Beli Manastir).

17 O prihvaćanju nacionalsocijalizma i Hitlera u njemačkoj naciji piše S. Haffner i zapaža sljedeće: “Nikoga ne bi začudilo da je to živo biće, dok je govorilo, neki pozornik povukao za ovratnik i odveo nekamo gdje se više nikad za njega ne bi čulo i kamo bez sumnje spada. Budući da se ništa slično nije dogodilo, budući da je taj čovjek, štoviše, išao sve dalje, bivao sve mahnitiji i monstruozniji i osim toga sve slavniji i nezaobilazniji u pogledu njegovog djelovanja došlo je do obrata: javila se fascinacija monstrumom." (Haffner, 2004.:97). 
Nacionalsocijalistička ideologija, s rasnom i etničkom superiornošću arijevaca i Nijemaca, kao ideologijski izričaj etničkog oblika nacije imala je izrazitu moć sugestije, posebno kod mladih pripadnika nacionalne zajednice. Gregarizam i socijalni konformizam oblici su reakcije pojedinaca na ponuđeni javni sadržaj, a izrazita ksenofobija i teški zločini u koje je prerasla popratni su efekti takvih sociopsiholoških obrazaca i individualnih reakcija na njih. Intervjuirani Nijemac to zorno pokazuje, ističući opreku svoje obitelji i tada euforične i agresivne nacionalsocijalističke propagande. Izgon iz zavičaja, odlazak prema Austriji i Njemačkoj i put u neizvjesno, vraćanje nazad i suočavanje s novim okolnostima u Slavoniji opisuje sljedeći intervjuirani Nijemac.

Otac je bio u njemačkoj vojsci, nas je pokupilo u školi. Stavili su nas u seljačka kola, kolima smo išli do granice, austrijske, onda su nas vratili nazad. U kolima smo bili sa susjedima. Konjska zaprega, bio je 5 mjesec 1945. g. Negdje oko Virovitice čuli smo krikove neke djevojke, imali smo oružanu pratnju. Djevojka je našla majku. Išli smo u Slavoniju, pred kraj puta smo naišli na vojni kamion sa šećerom u kockama. Počeli smo uzimati šećer, vojnici su nam dozvolili. Došli smo do rijeke, tamo je bilo puno oružja. Vojnici su natjerali te žene da vade oružja iz rijeke. Došli smo kući, nema ničega, prozore su uzeli ali su držali konje u kući. U Osijeku nam je tatina sestra dala brašno za kruh. Otac se vratio kući, nije bio predugo u logoru. Brat očev je bio u partizanima [...] mama je bila madarskog porijekla. Sa djecom nije bilo problema u školi. U općini je bilo problema sa dokumentima. Moji nisu razgovarali njemački, punac i punica jesu. Supruga je govorila njemački. Šutjeli smo o logoru, o svemu (Nijemac, muškarac, 79 g., Nova Bukovica).

Teške patnje u njemačkoj nacionalnoj zajednici nakon završetka rata kod Nijemaca koji su ostali u Jugoslaviji bile su tabu-tema. Svojevrsni zavjet šutnje bio je rezultanta više različitih reminiscencija i percepcija "onoga što se dogodilo", od sudjelovanja u njemačkoj vojsci, opće poslijeratne osude nacizma do revanšističke politike nove vlasti prema Nijemcima. O složenim međunacionalnim odnosima, političkim prilikama i ratnim događanjima saznajemo u sljedećem intervjuu.

Odnos starosjedilaca i Nijemaca [...] moj tata je bio u Osijeku. U dijelu grada su bili Nijemci. Tata nije bio u Kulturbundu, izjašnjavao se kao Hrvat. U 1941. g kada nastaje NDH, dobio je pištolj, dobili su nalog da otprate Dimitrijeviće (Srbe) do Zemuna, on se povukao, vratio je pištolj. Pred kraj rata oca su povukli u ekonomat domobranski, nakon toga se vratio kući. Otac je kroz prozor svoga stana slušao pjesmu: "Oj Staljine zdravo, zdravo, sve što radiš imaš pravo". Godine 1945., na kraju rata, partizanka dolazi u stan, njemu je našla drugi stan a ona se u njegov uselila [...] Tamo u tu kuću su dolazile još dvije obitelji. Vraćaju se vlasnici, živjeli smo tamo do 1971., normalni odnosi. (Nijemac, muškarac, 70 g., Osijek). 
Etnomimikrija se manifestirala i u tome što se izbjegavalo govoriti njemački jezik, a kako navodi intervjuirani, neki od oblika stigmatizacije bili su zastupljeni u školi, gdje je bilo dobacivanja.

Mama je bila u Kulturbundu, esekerski se govorilo u Osijeku. Pritisak je bio i u srednjoj školi. Mi smo 1947. g. primili državljanstvo, republičko pa savezno [...] Prije sam se deklarirao kao Hrvat, sada sam se deklarirao kao Nijemac. Mama nije mogla skrivati nacionalni identitet. Elitni dio Osijeka, tu su bili Švabe i Židovi (Nijemac, muškarac, 73 g., Osijek).

Etnomimikrija je bila način da se barem donekle smanji pritisak na pojedinca i njegovu obitelj. Osveta partizana, slanje na teški fizički rad i u logore, dezorijentacija u novom vremenu i različiti oblici terora prema Nijemcima sadržaji su narednog intervjua.

Nijemci su pokidali činove i pobacali vojne knjižice, otac je izvadio knjižicu i bacio u potok. Završio je u Borskom rudniku, bio je državljanin Srbije (otac) i radio u rudniku Bor. Partizanke su rezale spolovila Nijemcima, imale su napade. U Borskom rudniku radio je kao zarobljenik [...] 1947. g. došao je Mecunarodni Crveni križ, onda je se stanje poboljšalo. Nešto kasnije, 1948. g., uslijedio je Informbiro, onda su zarobljenike Nijemce pitali što misle da li su za Staljina ili za Tita. Otac je amnestiran [...] mogao je otici [...] pravi Nijemci to nisu pribvatili, onda su mu rekli da mora šest mjeseci služiti kod jednog Srbina na imanju. Srbi su im davali hranu, radio je kao sluga [...] barem se dobro najeo [...] U JNA oficir me je pitao koga ja imam u Njemačkoj. Kad sam pisao pismo morao sam donijeti otvoreno pismo (Nijemac, muškarac, 69 g., Belišće).

Dolazi do promjene etničke strukture u Baranji, malobrojni Nijemci boje se izraziti svoju nacionalnost, opredjeljenje za Mađare obilježava prve poslijeratne godine, što pokazuje naredni intervju.

Nakon rata je promijenjena etnička slika, a u Belom Manastiru Nijemaca skoro više nije ni bilo. Mi smo gotovo zaboravili govoriti njemački, a ponovno se učilo madarski i hrvatsko-srpski. Da nam bude lakše, mene je majka u školi deklarirala kao Madara, a tako je se deklariralo dosta Nijemaca jer je lakšse bilo biti Madar nego Nijemac (Nijemac, muškarac, 74 g., Beli Manastir). ${ }^{18}$

Integracija u poslijeratno društvo, školovanje, traženje posla sve je bilo otežano pripadnicima njemačke nacionalne zajednice, što potvrđuju i iznose intervjuirani.

18 Iako je admiral Horty surađivao s Nijemcima, uloga i posljedice, a shodno tome i stigma mađarske i njemačke nacionalne zajednice bile su različite, pa intervjuirani ističu da je i pored svih teškoća nakon Drugog svjetskog rata lakše bilo izjašnjenje za mađarsku nego za njemačku naciju. 
Meni su u školi dobacivali Švabo, psovali su mi švapsku majku. Brat i ja smo imali veze sa Srbima, a tako je bilo nešto laksé. Imao sam problem kod traženja posla, a slao sam više molbi, onda sam primljen u policiju. Majka mi je pritom sugerirala, ako te pitaju u vezi mojih i tvojih, nemoj komentirati [...]. Devedesetih, majka je rekla ocu da ode po moj krsni list. Ja tek tada saznajem da sam kršten u crkvi, tako da o svojoj povijesti tada više saznajem [...]. Nisam imao fizičkih napada ali verbalnih je bilo (Nijemac, muškarac, 57 g., Beli Manastir).

O istim temama, od etnomimikrije, straha za život do težeg uključivanja u poslijeratno društvo i križnim putevima, saznajemo u sljedećem intervjuu.

Križni put [...] došao do Dravograda, tjerali su ih do Sente, mobilizirani su u JNA [...]. Ujak Marko, bio je Slovak, živili su u šokačkom selu [...] partizani su kundačili učitelje, zatukli su ga, rezali su uši i nos". (Nijemac, muškarac, 70 g., Osijek).

Stigmatizacija pripadnika njemačke nacije u Hrvatskoj i bivšoj Jugoslaviji posljedica je događanja u Drugom svjetskom ratu, uloge Folksdojčera u njemu i odnosa partizanskog pokreta i kasnije socijalističkih vlasti prema Nijemcima. ${ }^{19}$ Intervjuirani Nijemci navode brojne primjere koji ilustriraju stigmatizaciju pripadnika nacionalne zajednice kojoj pripadaju. Još više od primjera nošenja stigme u školi, na ulici, u javnom životu ističu teške posljedice koje su povezane sa stigmom, i to prije svega onom koja je nametnuta odozgo kao sredstvo državne politike (Vrcan, 2003.). Problem stigme rase, plemena ili etničke zajednice ponajprije je u njezinoj generalizaciji i neselektivnosti u odnosu na društvenu grupu. Pripadnik je kriv neovisno o svojoj ulozi u grupi, pa je često predmet napada čak i u situaciji kada je bio u opoziciji onim aktivnostima za koje je ta grupa optužena. Kako se ovdje radi o "gustim", povijesnim procesima $s$ "ubrzanim" vremenom događanja, česta su stradanja toga tipa, s nemogućnošću dokazivanja i argumentiranja onoga što se je u zbilji dogodilo i uloga koje je stigmatizirani i napadnuti obnašao u tom vremenu. Stigma je postupno relaksirana, a biti Nijemac nije u kasnijem razdoblju socijalizma bilo toliko obilježeno. No ipak, tek su višestranačje u političkom ambijentu i uspostava Hrvatske kao samostalne države generirali reafirmaciju njemačkog nacionalnog identiteta, destigmatizaciju i izlazak iz dugotrajne i višedesetljetne etnomimikrije.

19 Analiza sadržaja novina Glas Slavonije, koje su izlazile 1943., 1944. i 1945.pokazuje kakav je bio medijski tretman Nijemaca na teritoriju pod kontrolom partizana. Novine su od 1. 5. 1945. počele izlaziti u Osijeku, a do tada na prostoru međurječja Dunava, Drave i Save, pod kontrolom partizana na oslobođenom teritoriju. U Glasu Slavonije se u navedenom razdoblju za Nijemce koriste sljedeći termini: Nijemac, okupator, Švabo, Hitler i fašist, u: Sučić, Mihael (2018.). "Prikaz Nijemaca u Glasu Slavonije", Osijek: Godišnjak njemačke zajednice, Vol. 25, str. 379-392. 


\subsection{Destigmatizacija Nijemaca i reafirmacija njemačkog nacionalnog identiteta u Republici Hrvatskoj}

Društvene i političke promjene koje su se devedesetih godina dvadesetog stoljeća događale u bivšim socijalističkim državama i društvima Srednje, Jugoistočne i Istočne Europe u svojim su temeljima, pored urušavanja socijalizma, imale i oživljavanje nacionalnih identiteta u federativnim državama, koje je završavalo zahtjevima za uspostavom nacije-države. S obzirom na dijelom federativne države u kojima se to događalo te etnički oblik nacije koji nije korespondentan s granicama države, sukobi između različitih nacija bili su dio tih procesa. U nekim slučajevima, posebno u bivšoj SFRJ, ti su sukobi završili ratovima. Pored dominantnih i brojčano većih nacija, demokratski procesi doveli su do reafirmacije i intenziviranja nacionalnog identiteta i kod onih nacionalnih zajednica koje su imale manjinski status. Jedan su od takvih primjera Nijemci u Hrvatskoj, a onda i u Slavoniji, koji su nakon razdoblja stigmatizacije u proteklim desetljećima obnovili i slobodnije počeli iskazivati pripadnost njemačkoj nacionalnoj zajednici, što se može označiti kao proces destigmatizacije. Sam proces destigmatizacije korespondira s reafirmacijom nacije i nacionalnog u procesu raspada bivših federativnih država i kolapsa socijalističkih poredaka u Istočnoj Europi, pri čemu nacija postaje temeljni obrazac političkog organiziranja. Demokratski politički procesi, uz navedeno, pridonijeli su reafirmaciji nacionalnih identiteta te omogućili i destigmatizaciju njemačke nacionalne zajednice u Hrvatskoj. Što o destigmatizaciji kažu intervjuirani Nijemci?

Poslije 90-e sam mogao reći da sam Nijemac, Švabo [...] prije toga to je bila pogrdna riječ (Nijemac, muškarac, 79 g., Nova Bukovica).

Za reafirmaciju njemačkog nacionalnog identiteta važna je i pomoć Njemačke, a u okviru toga materijalna pomoć ima posebnu težinu. Sve to navodi intervjuirani Nijemac iz Osijeka.

Njemačka narodnosna zajednica [...] Zemaljska udruga Podunavskih Švaba. Simpoziji, kazališni festivali [...] zatim Svjetski savez Podunavskih Švaba, sve su to udruge i manifestacije važne za očuvanje našeg identiteta. Njemačka je službena adresa za sve Nijemce izvan Njemačke. Podržavaju nas, imaju svoje novce za naše programe. Preko tih udruga smo dobili 2500 eura, odštetu za prisilni rad za Nijemce civile [...] Običaji, gastronomija su važni kao sjećanje na prošlost i pronošenje identiteta. Na Badnjak se kuhao fiš, pjevalo se Stille Nacht, tiha noć. Oko 150000 Nijemaca je živjelo na području Hrvatske (Nijemac, muškarac, 70 g., Osijek).

Multinacionalni ambijent, uz obitelj koja ima različite etničke korijene, rezultira višestrukim vezama u lokalnoj zajednici te prakticiranjem raznolikih običaja i gastronomskih aktivnosti. $\mathrm{O}$ važnosti nacionalnog identiteta i međunacionalnim odnosima u Slavoniji saznajemo iz narednog intervjua. 
Živjeli smo sa djedom i bakom Klein. U Osijek sam došla 1983. godine. Mi smo trojezični, [...] govori se madarski, hrvatski, njemački. Moja obitelj je vrlo ponosna na svoje porijeklo, njemačko. Nikada o tome nismo šutjeli. Imala sam sreću da sam odrasla u vrlo mješovitoj sredini [...] Slavili smo Đurđevdan sa Romima. Običaji, gastronomija, post je bio na veliki petak. Običaj u kući je kuhanje fiša, kotlić, djed je sam radio rezance [...] Bački švapski smo govorili [...] postoji razlika. C model je na snazi uškoli Sv. Ana, Osijek, OŚ Retfala, takoder njegujemo njemački jezik. Od sedamdesetih godina, nakon ukidanja ruskog, datira njemački kao strani jezik. Njemački upisuju i oni koji nisu Nijemci porijeklom (Njemica, žena, 64 g., Stara Moravica).

U Osijeku se učenici Nijemci, ali i drugi obrazuju u modelu C, a suživot je u kontinuitetu i u stalnom iskušenju.

Dosta Nijemaca su sada Hrvati njemačkog porijekla [...] sad smo Hrvati jer smo ugroženi od Srba. Njegovanje tradicije [...]. Pjevam u crkvenom zboru. Nikola Mak me nagovorio na pjevanje i angažman (Nijemac, muškarac, 70 g., Osijek).

O popisima stanovništva, asimilaciji i odnosu prema nacionalnom saznajemo od intervjuirane Njemice. Izgubilo se puno vremena, dosta ljudi se asimiliralo. Obitelj me nije odgajala u mržnji prema drugima, prema nikome [...]. Kod svakog popisa stanovništva mi smo bili Ostali. Od 1991. u Popisu pa i nadalje u svim drugim Popisima stanovništva smo Nijemci. Sestrična se udala za Madara [...] neko vrijeme nakon rata i u socijalizmu bili smo nezainteresirani za nacionalnost. (Nijemaca, žena, 64 g., Stara Moravica).

Destigmatizacija Nijemaca događa se krajem devedesetih godina dvadesetog stoljeća i koincidira sa strukturalnim društvenim i političkim promjenama u tadašnjim socijalističkim državama. Nijemci se izjašnjavaju u popisima stanovništva u suglasju sa svojim nacionalnim osjećajem, izostaje etnomimikrija temeljena na stigmi vezanoj za Drugi svjetski rat i strah koji je reproduciran u socijalističkom poretku. Ono što ističu intervjuirani Nijemci svakako je izgubljeno vrijeme u kojem su asimilacija kao i ostali sociopolitički i sociopsihološki hendikepi rezultirali smanjivanjem ionako već malobrojnih Nijemaca nakon završetka Drugog svjetskog rata. Devedesetih godina dvadesetog stoljeća i dalje stigma nije više opterećivala Podunavske Švabe, koji se osjećaju slobodnije, a uloga Njemačke, kao i međudržavni odnosi između Njemačke i Hrvatske, pritom su bili izrazito afirmativni činioci i procesi. Udruge Nijemaca u Slavoniji i u Hrvatskoj značajno su financirane od njemačke države, što omogućuje očuvanje nacionalnog identiteta i figurira kao brana od asimilacije. Reafirmacija nacionalnog identiteta, pored slobodnijeg izražavanja u primarnosocijalnoj sferi, ponajprije u obitelji i u susjedstvu, događa se i u oblicima sekundarne socijalizacije, posebno u obrazovanju. Model C i njegovo korištenje od pripadnika njemačke nacionalne zajednice indikator je za navedeno. 


\section{Zaključna razmatranja}

Njemačka nacionalna zajednica bila je pred Drugi svjetski rat među brojnijima u $\mathrm{Hr}$ vatskoj. Povijest doseljavanja njezinih pripadnika seže u daleku prošlost, ali znatniji broj migranata iz korpusa te nacionalne zajednice dolazi u postosmanskom razdoblju, u sklopu kolonizacije koju je organizirala Austro-Ugarska s ciljem naseljavanja opustjelih krajeva. U Slavoniju Nijemci u okviru kolonizacijske politike stižu sredinom 18. stoljeća i naseljavaju Vojnu Krajinu i civilni dio Slavonije, i to u najvećem broju vlastelinska imanja Eltz, Pejačević i druga. Empirijsko istraživanje daje nam uvid, posredstvom komunikacijskog sjećanja ispitanika, u razloge/motive doseljenja njihovih predaka, načine dolaska i socijalnu interakciju doseljenika s domicilnim stanovništvom, temeljeno na informacijama koje su intervjuirani usvojili u svojoj primarnosocijalizacijskoj sferi (komunikacijsko pamćenje/sjećanje). Migranti dolaze Dunavom, a njihovi motivi su: izlazak iz kmetskog statusa i osiguranje egzistencije za sebe i obitelj, pri čemu je, prema iskazima intervjuiranih, gotovo žrtvovana prva generacija useljenika. Tek neke naredne generacije, uglavnom od treće nadalje, počinju koristiti efekte kolonizacije, rada i zalaganja predaka i vlastitog angažmana. Prostori s kojih su migranti stizali bili su industrijski i uopće gospodarstveno razvijeniji u odnosu na društvo prijema, što se u istraživanju argumentira već prethodnim dolascima obrtnika kao i revolucioniranjem tadašnje poljoprivrede u Slavoniji (željezni plug, korištenje stajskog gnojiva u polju i sl.). Po dolasku u Slavoniju Nijemci zatiču domaće stanovništvo različite etničke i vjerske pripadnosti (Hrvati, Srbi, Mađari, katolici, pravoslavni i drugi). Kao i u sličnim takvim situacijama, nameće se pitanje međusobne koegzistencije (suživota) pripadnika tih različitih entiteta. U prvim godinama nakon useljavanja Nijemaca u Slavoniju socijalna se interakcija događa više unutar grupe, pa se primarnosocijalizacijski obrasci, kao što su bračne veze, kumstva i prijateljstva, uglavnom oblikuju na taj način. $S$ protokom vremena ženidbene i druge veze postaju transgrupne, pa dolazi do nacionalno mješovitih brakova i drugih sličnih oblika primarne socijalne interakcije. $U$ istraživanju se navode primjeri vrlo kvalitetnog suživota, sve do poznavanja jezika i komunikacije na jeziku susjeda druge nacionalnosti. Nasuprot predviđanjima o smanjenju utjecaja i značaja nacije i nacionalnog identiteta u kasnom dvadesetom stoljeću, dogodilo se njihovo oživljavanje. To je posebno snažno afirmirano tamo gdje je došlo do raspada socijalističkih poredaka, a i nekih federativnih država (Srednja i Istočna Europa). Nacionalni identitet u društvima s etničkim oblikom nacije postaje resurs/platforma za konstituiranje nacije-države, što izrazito povećava njegov kapacitet, a to se istovremeno dovodi u korelaciju s ostalim nacionalnim diverzitetima. U toj igri moći situacija je $s$ temeljnim kolektivnim identitetom, u ovom slučaju nacionalnim, različita i zavisi od više sociopolitičkih činilaca. Tako su u Hrvatskoj, uz predominantni hrvatski etnički identitet, ostali takvi kolektivni identiteti zauzeli različite pozicije. Njemačka nacionalna zajednica iz više je razloga reafirmirala do tada uglavnom potisnut kolektivni identitet vlastite zajednice. Pripadnici njemačke nacionalne manjine u određenom su broju sudjelovali u nacionalsocijalističkom osvajačkom i genocidnom projektu, a velika većina Nijemaca pri kraju rata i u poraću teško je stradala od pripadnika partizanskog po- 
kreta, obuhvaćeni stigmom neprijatelja i poraženih snaga nacizma. Destigmatizacija, uz reafirmaciju nacionalnog identiteta te zajednice, događa se u vremenu tranzicije iz jednopartijskog socijalističkog u višestranački demokratski poredak te u procesu disolucije SFRJ. Drugi važan razlog koji je dodatno afirmirao njemački identitet pomoć je tadašnje njemačke države novo uspostavljenoj hrvatskoj državi, od materijalne do političke, što pridonosi afirmaciji njemačke zajednice u Hrvatskoj.

\section{Literatura}

1. Abercrombie, N.; Hill, S. i Turner, S. B. (2008). Rječnik sociologije. Zagreb: Naklada Jesenski i Turk (urednici hrvatskog izdanja: Jadranka Čačić-Kumpes i Josip Kumpes).

2. Adorno, T. i Horkheimer, M. (1980). Sociološke studije. Zagreb: Školska knjiga.

3. Anderson, B. (1990). Nacija: zamišljena zajednica. Zagreb: Školska knjiga.

4. Babić, D. (2008). Suživot Hrvata i Srba u Slavoniji: (re)konstrukcija multietničkih lokalnih zajednica nakon ratnih sukoba. Zagreb: Golden marketing-Tehnička knjiga.

5. Babić, D. (2010). Etnonacionalizam i ratu Hrvatskoj: teorijski aspekti i istraživanje međunacionalnih odnosa u lokalnim zajednicama. Zagreb: Plejada.

6. Barry, B. (2006). Kultura i jednakost: egalitarna kritika multikulturalizma. Zagreb: Naklada Jesenski i Turk.

7. Bauer, L. (1990). Kratka kronika porodice Weber. Sarajevo: Svjetlost.

8. Beus Richemberg, G. (2010). Nijemci, Austrijanci i Hrvati. Prilozi za povijest njemačko-austrijske nacionalne manjine u Hrvatskoj i Bosni i Hercegovini. Zagreb-Sarajevo: Synopsis. Osijek: Njemačka zajednica - Zemaljska udruga Podunavskih Švaba u Hrvatskoj.

9. Blažević, R. (2003). Tribalna stigma i nacionalizam, u: Zbornik Pravnog fakulteta Sveučilista u Rijeci. Rijeka, god. 24, br. 2, 795-804.

10. Bogdanović, M. (2003). Stigma i kako je steći: tribalna i karakterna stigma u proteklom ratu na prostoru bivše Jugoslavije, u: Zbornik Pravnog fakulteta Sveučilišta u Rijeci. Rijeka, god. 24, br. 2, 907-912.

11. Devereux, G. (1990). Komplementaristička etnopsihoanaliza. Zagreb: August Cesarec.

12. Galiot, Kovačić, J. (2008). Gospodarski i kulturni utjecaji njemačkih doseljenika na tradicijski život Slavonije, Baranje i zapadnog Srijema, od početka 18. stoljeća do 1941. godine. Etnološka tribina, Zagreb, Etnografski muzej Zagreb. No 12/13, 213-237.

13. Geiger, V. (2005). Nijemci u Hrvatskoj (od srednjega vijeka do naših dana), u: Stanovnistvo Hrvatske-dosadašnji razvoj i perspektive. Zagreb: Institut društvenih znanosti Ivo Pilar, 277-292.

14. Geiger, V. (2008). Josip Broz Tito i sudbina jugoslavenskih Nijemaca. Časopis za suvremenu povijest, 40 (3): 789-818. 
15. Geiger, V. (2018). Sudbina njemačke manjine u Hrvatskoj i Jugoslaviji potkraj Drugoga svjetskog rata i u neposrednom poraću, u: Stradanje Madara i Nijemaca u Hrvatskoj i Bačkoj 1944./45. Zagreb-Budimpešta: Društvo mađarskih znanstvenika i umjetnika u Hrvatskoj. Zagreb: Nova stvarnost, Zagreb, Croatica, Budimpešta.

16. Goffman, E. (1968). Stigma. Management of Spoiled Identity. Harmondsworth: Penguin Books.

17. Haffner, S. (2004). Povijest jednog Nijemca: sjećanja 1914.-1933. Zagreb: Duriex.

18. Kolar-Dimitrijević, M. (2001). Skrivene biografije nekih Nijemaca i Austrijanaca u Hrvatskoj 19. i 20. st. Osijek: njemačka narodnosna zajednica-Zemaljska udruga Podunavskih Švaba.

19. Kymlicka, W. (2003). Multikulturalno gradanstvo. Zagreb: Naklada Jesenski i Turk.

20. Laušić, A. (1991). Iz povijesti folksdojčera i njjihova egzodusa na tlu Jugoslavije. Migracijske teme, 7 (2): 183-192.

21. Leček, S. (2017). Slavonski Nijemci - 'najmanje poznati sunarodnjaci'. u: Godišnjak njemačke zajednice. Vol. 15: 121-138.

22. Mažuran, I. (1988). Popis naselja i stanovništva u Slavoniji 1698. godine. Osijek: JAZU, radovi Zavoda za znanstveni rad u Osijeku.

23. Mesić, M. (1992). Osjetljivi i ljuti ljudi. Zagreb: Ured za prognanike i izbjeglice Vlade Republike Hrvatske. Institut za migracije i narodnosti Sveučilišta u Zagrebu.

24. Mesić, M. (2012). Je li (njemački) multikulturalizam mrtav?, u: Lošonc, A. i Prole, D. (Ur.). Aporije multikulturalizma. Novi Sad: Centar za multikulturalnost.

25. Plessner, H. (1997). Zakašnjela nacija: o političkoj zavodljivosti gradanskog duha. Zagreb: Naprijed.

26. Pusić, E. (1963). Lokalna zajednica. Zagreb: Narodne novine.

27. Rasković, A. (2017). Povijest njemačke pučke škole u Osijeku-Retfala 1816.1945., u: Godišnjak njemačke zajednice, Vol. 15: 313-319.

28. Rodinis, A. (2017). Odjeljenja s njemačkim jezikom u odjelima pučkih škola u kotarima Vukovar, Vinkovci i Županja od 1929. do 1931. godine, u: Godišnjak njemačke zajednice, Vol. 24: 243-264.

29. Roth, K. (2000). Slike u glavama: ogledi o narodnoj kulturi u jugoistočnoj Evropi. Zemun. Biblioteka XX vek; Beograd: Čigoja štampa.

30. Sučić, M. (2018). Prikaz Nijemaca u Glasu Slavonije. Godišnjak njemačke zajednice, Vol. 25: 379-392.

31. Šabić, V. (2002). Tradicijski život Mađara i Nijemaca u Retfali, dijelu Osijeka. Etnolološka tribina. Zagreb, Etnografski muzej Zagreb. 25, Vol. 32, 105-120.

32. Šnajder, S. (2016). Doba mjedi. Zagreb: TIMpress. 2. izdanje.

33. Šojat Kuči, I. (2009). Unterstadt. Zagreb: Fraktura. 
34. Trischler, R. (2007). Njemačka narodnosna zajednica-Zemaljska udruga Podunavskih Švaba u Hrvatskoj, u: Smoje, M. (Ur.). Nacionalne manjine u Osijeku. Osijek: Grad Osijek.

35. Vlaisavljević, U. (2018). Aporije suživota. Ka etnologiji bliskih stranaca. MostarSarajevo-Zagreb: Sveučilište u Mostaru. Synopsis d.o.o. Sarajevo. Synopsis d.o.o. Zagreb.

36. Vrcan, S. (2003). O političkim inscenacijama stigmatizacije: od folklornih do državno-političkih inscenacija stigmatizacije, Zbornik Pravnog fakulteta Sveučilišta u Rijeci, Rijeka: br. 2, 2003, 719-733.

37. Vujačić, I. (2010). Politika identiteta, multikulturalizam i manjinska prava. Međunarodne studije, 10 (3/4): 5-17.

38. Živaković-Kerže, Z. (2009). Drava-etnička i gospodarska odrednica, u: RittigBeljak, N. i Marks, Lj. (Ur.). Povijesne zaobilaznice. Nijemci i Austrijanci u Hrvatskoj. Zagreb: Zajednica Nijemaca u Hrvatskoj.Institut za etnologiju i folkloristiku, 104-111.

39. Živaković-Kerže, Z. (2018). Istaknuti Nijemci i Austrijanci u nazivima osječkih ulica. Godišnjak njemačke zajednice, Vol. 25: 409-422.

40. Živić, D. (1998). Promjena narodnosnog sastava stanovništva gradskih naselja Istočne Hrvatske 1910.-1991. godine. Migracijske teme, 14 (1/2): 99-127.

41. Župančić, V. (2017). Potraga za domovinom. Mala povijest njemačkih evangelika na hrvatskom prostoru. Osijek: Kršćanski centar 'Dobroga pastira'.

42. Županov, J. (1998). Etničnost i politika na europskom geopolitičkom prostoru, u: Čičak-Chand, R. i Kumpes, J. (Ur.). Etničnost, nacija, identitet. Zagreb. Institut za migracije i narodnosti, Naklada Jesenski i Turk, Hrvatsko sociološko društvo.

\section{Izvori}

Popis stanovništva 1991., Dokumentacija 881. Zagreb: Državni zavod za statistiku, 1992.

Popis stanovništva 1991., Dokumentacija 889. Zagreb: Državni zavod za statistiku, 1996.

Popis stanovništva 2001., Zagreb: Državni zavod za statistiku, 2002.

Popis stanovništva 2011., Zagreb: Državni zavod za statistiku, 2013.

Ustav RH, Narodne novine, br. 76, Zagreb, 2010. g.

Ustavni zakon o pravima nacionalnih manjina, Zagreb, $2002 \mathrm{~g}$.

Zakon o uporabi jezika i pisma nacionalnih manjina u Republici Hrvatskoj, Zagreb, 2000. g.

Zakon o odgoju i obrazovanju na jeziku i pismu nacionalnih manjina, Zagreb, 2000. g. 


\title{
Germans in Slavonia: From Coexistence through Stigma to the Reaffirmation of National Identity
}

\author{
Dragutin Babić \\ Institute for Migration and Ethnic Studies, Zagreb, Croatia \\ e-mail: dragutin.babic@imin.hr
}

\begin{abstract}
This paper analyses the German national minority in Osijek and Baranya, based on empirical research (interviewing) conducted in Osijek and Beli Manastir. The questions in interviews encompassed the memories of the Germans (Danube Schwabians) regarding the arrival and acceptance of their ancestors, through the coexistence they established with the Croats, Serbs, Hungarians and others, to the WWII occurences, which radically changed the number, social status and complete existence of these nationals. A part of the ethnic Germans (Volksdeutsche) greeted the National Socialist mobilization in Kulturbund with delight, and a part of the Germans was actively involved in German military formations, which severely undermined the pre-war relations between the nations in the local communities. Through the war activities of partisans and particularly through their war victory and establishment of the new authorities, the German national community was almost completely stigmatized as the occupiers and adversaries. A slight exception were the Germans who participated in the National Liberation War and those that were treated as supporters and facilitators. The rest, and this was the great majority, were expelled from their homes, sent to concentration camps, murdered and forced to exile. The socialist paradigm of the WWII interpretation was mostly binary, with an intensive dichotomy of We/Good - They/Evil, concealing many niches within these occurences, especially those at the micro-level, which were not plain and unambiguous. The group of the defeated, that by generalization included almost all Germans, did not have the right to remembrance. The stigma was extremely strong and any memory of WWII outside the official ideological framework was not advisable, and in the first years after the war even dangerous. It was first in 1990 that the collapse of socialism and the federal state and the introduction of elementary democratic norms in the public sphere enabled the destigmatization of the German national minority. The interviewed Germans kept in their communicational memory the knowledge of their ancestors' arrival, the problems they were facing, the first forms of coexistence, and the severe destruction of that coexistence during and after WWII. The revival of the national identity after the 1990s strengthened the small German community and enabled its visibility in the public sphere, the slowing down and even stopping of assimilation, further destigmatization and coming out of ethnomimicry.
\end{abstract}

Key words: the Germans, Slavonia, coexistence, stigma, national identity. 